UNIO - EU Law Journal. Vol. 4, No. 2, July 2018, pp 77-89.

®2018 Centre of Studies in European Union Law

School of Law - University of Minho

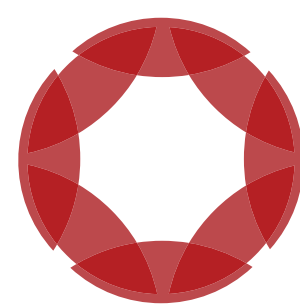

\title{
A challenge for copyrights in the Digital Single Market: the editing of out-of-commerce works
}

\author{
Isabel Espín Alba*
}

ABSTRACT: This article makes a critical description of the statute of the licenses for the exploitation of works out-of-commerce envisaged in the Proposal for a Directive of the European Parliament and the Council on copyright in the Digital Single Market of September 14, 2016. In addition to the analysis of the precepts of the aforementioned Proposal, its main back.grounds are analysed, e.g., the Memorandum of Understanding on Key Principles on the Digitisation and Making Available of Out-of-Commerce Works, the French normative experience and the Soulier and Doke case (Judgment of the Court of Justice of the European Union of November 16, 2016).

KEYWORDS: Digital Single Market - copyright - intellectual property - limits on authors rights - out-of-commerce works.

\footnotetext{
* Professor of Private Law at the Faculty of Law of the University of Santiago de Compostela.
} 


\section{Digital Single Market and challenges of copyright. Preliminary considerations}

Based on Article 4(2)(a) and Articles 26, 27, 114 and 115 of the Treaty on the Functioning of the European Union, we are immersed in a complex legislative process that manifests itself in the Digital Single Market (DSM), ascertained as the elimination of trade barriers between Member States with the aim of increasing economic prosperity and contributing to "an ever closer union among the European peoples" and further developing the concept of the internal market, defined as "area without internal frontiers in which the free movement of goods, persons, services and capital is ensured" [Article 26(2), Treaty on the Functioning of the European Union].

The free circulation of information, knowledge and content, together with the new forms of creation of intellectual goods and services, are shaped in the DSM upon the pillars of the four basic freedoms of the single market (free movement of people, goods, services and capital).

As far as copyright is concerned, the Strategy for the Digital Single Market, presented on May 6, 2015, advances several measures related to the improvement in the protection of intellectual property rights, which must coexist with other interests, sometimes clashing, as for example, simpler access by the users to protected content facing the expectations of economic retribution by the holder of rights over the same works or services.

Of all initiatives, the intention to undertake modifications in the field of limits or exceptions to intellectual property will be highlighted, as set out in the Communication of the Commission to the European Parliament, the Council, the European Economic and Social Committee and the Committee of the Regions, Promoting a fair, efficient and competitive European copyright-based economy in the Digital Single Market, of September 14, 2016. ${ }^{1}$ More specifically, the Proposal for a Directive of the European Parliament and of the Council on copyright in the Digital Single Market, of September 14, 2016 (hereinafter, Proposal for a Directive), to which we must add the promotion of more appropriate mechanisms for the licensing of protected content.

The analysis of the contents of the Proposal for a Directive ${ }^{3}$ delimits a number of matters relating to the exceptions of copyrights that will be amended. The willingness of its adequacy to the new demands of the digital market has been considerably diluted, as the most controversial limits and the mechanisms of fast access to the contents have not been regulated.

In the face of this double focus - limits, on one hand ${ }^{4}$, and licensing, on the other -, the object of the present paper (the editing of out-of-commerce works) could have been regulated, just as the orphan works have, concerning the limits or waivers. Yet, since its background and following evolution, EU law has situated that

\footnotetext{
${ }^{1}$ COM (2016) 592 final.

${ }^{2}$ COM (2016) 593 final.

${ }^{3}$ For an approach to the general lines of the reform, see Aurelio López-Tarruella Martínez, "La reforma del sistema de los derechos de autor en la Unión Europea. Estado de la cuestión”, Revista La Propiedad Inmaterial 22 (2016): 101-139.

${ }^{4}$ On the dangers of excessively extending the list of limits to copyright, even if they are remunerated, see Rodrigo Bercovitz Rodríguez-Cano, "El mercado único digital y la propiedad intelectual”, Revista Doctrinal Aranzadi Civil-Mercantil 2 (2016).
} 
topic in the area of licences and contracts ${ }^{5}$ in a way that the issues of the editing of out-of-commerce works will follow contractual mechanisms of resolution, as provided for in Title III of the Proposal for a Directive - and not in its Title II.

With reference to Title II, it contains actions to adapt the exceptions and limits to the digital and cross-border landscape and in three articles it approaches:

a) Text and data mining made by research organisations for the purposes of scientific research (Article 3). The intention is to introduce a specific limit - as there already exists in some States (for example, France, 2016) - that allows researchers to proceed with data mining and text mining. The starting point is that EU law already establishes certain waivers and limitations regarding the uses for the purposes of scientific research which can be applied to acts of text and data mining. Such mechanisms, though, have so far an optional nature and they are not fully adjusted to the use of mining technology in scientific research.

b) The digital use of works and other subject-matter for the sole purpose of illustration for teaching (Article 4). It is a question of ensuring that the centres of education enjoy total legal certainty when they use works or other provisions in digital learning activities, including online and cross-border activities.

c) It determines a limit in favour of cultural heritage institutions which permits the copy of works or other subject-matter that are permanently in their collections for purpose of their preservation (Article 5).

On the other hand, Chapter 1 of Title III begins with measures to improve the granting of licences and to ensure a larger access to the contents and it refers specifically to the out-of-commerce works (Article 7).

Recital 23 of the Proposal for a Directive anticipates that Member States should have flexibility in choosing the specific type of mechanism allowing for licences for out-of-commerce works to extend to the rights of rightholders that are not represented by the collective management organisation in accordance with their legal traditions, practices, or circumstances. Such mechanisms can include extended collective licensing and presumptions of representation.

Closing Chapter 1 of Title III, the cross-border effect of the licence granted is guaranteed (Article 8) and the Member States are bound to keep regular dialogue among stakeholders about the questions regarding out-of-commerce works and their licences (Article 9).

Chapter 2 of Title III, in Article 10, presents the obligation for Member States to implement assistance by an impartial body to facilitate negotiations on online use of audio-visual works.

\section{Context. Cultural institutions and publishing rights}

To understand the reason and scope of the choice for the contractual means facing the imposition of limitations, some elements of the normative evolution on the subject can be analysed.

The last two decades have been marked by a profound change in the publishing market. New channels of creation, distribution and public communication of artistic and literary content, divide space with greater interaction between creators and the

\footnotetext{
${ }^{5}$ On this topic, see Raquel Xalabarder, "Las obras huérfanas y las obras descatalogadas", Propiedad intelectualy Sociedad de la Información, ed. Fernando Carbajo (Madrid: Wolters Kluwer, 2012), and Raquel Evangelio Llorca, "Un nuevo reto para la digitalización y puesta a disposición de obras intelectuales: el uso de obras huérfanas y descatalogadas”, Diario La Ley 7884 (2012).
} 
public, which are no longer mere passive consumers.

In any case, the main asset of publishers continues to be their catalogue of works, backed by the contracts concluded with their authors for the assignment of editing rights.

In what is being discussed here, as regards availability in the market, the difference between discontinued works and works in commercial circulation disappears once anyone who makes a copy of the book or disc can copy, reproduce and distribute it digitally with costs and speed that forgo traditional marketing channels.

On another level, new technologies are also presented as a powerful tool to streamline and secure copyright management processes, with the aim of ensuring a more effective administration of content and their rights.

The out-of-commerce works are protected by copyright, but are not available by the decision of the owners of rights to not publish more editions (printed or electronic). At that time, the printed or digitized copies contained in the collections of cultural institutions, such as libraries and archives, are a privileged means of access to the works, but to carry out this mission of conservation and dissemination of cultural contents, it is necessary for such institutions to have a secure and stable legal framework that allows them to have the appropriate licenses to digitize and make their funds available.

The licensing system starts from the consideration of the contractual reality of the sector, in the line marked by the CJEU in the Soulier and Doke case. ${ }^{6}$ The key is respect for the author and the rights holders derived from the contracting.

Traditionally, in the different legal systems, the contract for the edition of literary or scientific works of art has been characterized as an assignment of the rights of reproduction and distribution of the object of the contract. With the emergence of digital technologies, to these exploitation rights has been added the cession of the right of public communication, in its form of online availability of the contents.

In the case of Spanish legislation (LPI), and as a technique of public order for the protection of authors, a minimum content has been imposed for the publishing contract (Articles 60 and ff.) and a series of presumptions for the assignment of rights in general (Articles 43 and ff.). The written form for them has, therefore, been generalized.

It is a contract in which the business risk is assumed by the publisher who, personally or with the collaboration of third parties, is responsible for editing in the terms agreed in the transfer of rights and distributing the copies (in the case of the analogical edition) in the market, guaranteeing a correct commercial exploitation.

Well, for the purposes that interest us, many of the contracts concluded in recent decades contained a very long term and, despite the obligation of the publisher to ensure the work a continuous exploitation and commercial dissemination according to customary uses in the professional sector of the edition, it is frequent that on the out-of-print or out-of-commerce works, editing rights of the publishers are still in force.

In this way, any activity related to the digitalisation of discontinued works or out-of-commerce requires the authorisation of the holders of intellectual property rights, copyright or related rights.

The Proposal for a Directive shows a specific interest in the mechanisms that allow the recovery of 'forgotten books', and give them a new life, as an unprecedented

${ }^{6}$ Judgment Soulier and Doke, case C-301/15, 16 November 2016, ECLI:EU:C:2016:878. 
opportunity for European citizens to have access to works that otherwise would have indeed been forgotten.

\section{European solution: non-exclusive licence for non- commercial purposes}

\section{Backgrounds}

\subsection{The $M o U$}

In 2006, a High Level Expert Group on Digital Libraries was created, composed by representatives of the various people affected by digitalisation and online accessibility of cultural material, in order to study, inter alia, the question of orphan works and discontinued works ${ }^{7}$ and whose results are reflected in the approval in 2008 by the Group of the "Final Report on Digital Preservation, Orphan Works and Out-ofPrint Works". Afterwards, and upon the basis of the tasks carried out by that Group, it was elaborated the report of the Comité des Sages "New Renaissance" on Digitisation of Europe's cultural heritage, of 10 January 2011 and which has played an important role of doctrinal anchoring to the search for new efficient economic models that speed up digitalisation and allow equitable remuneration of copyright holders and related rights when appropriate. ${ }^{9}$

Both topics - out-of-commerce works and orphan works - became part of the EU strategy set out in the "Digital Agenda for Europe 2010"10 and in the objectives of the Commission on intellectual property detailed in the "Communication on a Single Market for Intellectual Property Rights", from 24 May $2011^{11}$ Indeed, the key action 1 of the Digital Agenda for Europe highlighted the need to "simplify copyright clearance, management and cross-border licensing" with an explicit reference to the creation of a "a legal framework to facilitate the digitisation and dissemination of cultural works in Europe by proposing a Directive on orphan works [...], [and] to conduct a dialogue with stakeholders with a view to further measures on out-of-print works, complemented by rights information databases". ${ }^{12}$

With this starting point, a crucial strategy for the development of a knowledgebased economy is the creation of European digital libraries that conserve and disseminate the rich cultural and intellectual heritage of Europe, and for it the Directive $2012 / 28 / \mathrm{EU}^{13}$ has been adopted and at the same time sponsored the celebration of

\footnotetext{
${ }^{7}$ Commission Decision of 27 February 2006 setting up a High Level Expert Group on Digital Libraries, DO L 63 of 04/03/06, p. 25-27. The Group was subsequently renewed by Commission Decision of March 25, 2009, DO 82 of 28/03/09, p. 9-11.

${ }^{8}$ Final Report on Digital Preservation, Orphan Works and Out-of-Print Works. Available on: http://travesia. mcu.es/portalnb/jspui/bitstream/10421/1742/1/inf_final_preserv_dig_obras_huerfanas_2008.pdf.

${ }^{9}$ http:/ / europa.eu/rapid/press-release_IP-11-17_en.htm.

${ }^{10}$ Communication from the Commission to the European Parliament, the Council, the European Economic and Social Committee and the Committee of the Regions "A Digital Agenda for Europe", COM (2010) 245 final $/ 2$.

${ }^{11}$ Communication from the Commission to the European Parliament, the Council, the European Economic and Social Committee and the Committee of the Regions "A Single Market for Intellectual Property Rights Boosting creativity and innovation to provide economic growth, high quality jobs and first class products and services in Europe", COM (2011) 287 final, available on http://ec.europa.eu/internal_market/ copyright/docs/ipr_strategy/COM_2011_287_en.pdf.

${ }^{12}$ https://eur-lex.europa.eu/legal-content/en/ALL/?uri=CELEX\%3A52010DC0245R\%2801\%29.

${ }^{13}$ Directive 2012/28/EU of the European Parliament and of the Council of 25 October 2012 on certain permitted uses of orphan works. About this Directive on certain authorized uses of orphan
} 
a Memorandum of Understanding $(\mathrm{MoU})$ between libraries, publishers, authors and copyright collecting agencies to facilitate solutions in terms of licenses to digitize and make available books out of commerce.

Such Memorandum of Understanding on Key Principles on the Digitisation and Making Available of Out-of-Commerce Works, signed on 20 September 2011 by representatives of European libraries, authors, publishers and copyright collecting entities ${ }^{14}$ and attested by the European Commission (EC), makes a commitment to the licensing mechanism in the book sector, agreed between the economic agents involved (authors, publishers, booksellers). ${ }^{15}$

The MoU agreed between libraries and archives and management entities and editors is presented as a tool to develop the work of cultural institutions of public access listed in Article 5(2)(c) of Directive 2001/29/EC.

The keys of the MoU can be summarized in that it is a specific sectorial agreement (books and specialized magazines), based on voluntary licenses negotiated in the country of the first publication of the work and in the attribution of the condition of out-of-commerce work by the country of the first publication, according to the criteria established by the parties. Likewise, one of the notable aspects of the agreement is the content and scope of the agreed licenses, and the anticipation of the need to find solutions to collective management situations when not all rights holders are represented by a management entity. From a terminological point of view, its object does not coincide exclusively with the idea of out-of-print editions or out-of-print books, since it has preferred to focus on the idea of commercial availability in the market, to also include literary works in electronic format, to which the discontinuation is an inexistent concept.

In the Communication Towards a modern, more European copyright framework ${ }^{16}$, the EC expressed its interest for the fair pay of authors and performers, who may be particularly affected by differences in bargaining power when granting licenses or assigning their rights. Mechanisms cited by stakeholders in this context include the regulation of certain contractual practices, irrevocable remuneration rights, collective bargaining and the collective management of rights.

works and their transposition in Spain, see, among others: Ana Tobio Rivas, "Las obras huérfanas", Revista de Derecho Mercantil 303 (2017): 35-66; Susana Checa Prieto, La explotación comercial de las obras buérfanas (Valencia: Tirant lo Blanch, 2017); Pilar Cámara Águila, “Artículo 37 bis”, Comentarios a la Ley de Propiedad Intelectual, ed. Rodrigo Bercovitz (Madrid: Tecnos, 2017); Rafael Sánchez Aristi, "El nuevo límite de obras huérfanas", La reforma de la Ley de Propiedad Intelectual, ed. Rodrigo Bercovitz (Valencia: Tirant lo Blanch, 2015); Isabel Espín Alba, Obras buérfanas y derechos de autor (Cizur Menor: Aranzadi, 2014).

${ }^{14}$ The agreement was signed by the European Writers' Council (EWC), the Federation of European Publishers (FEP), the European Publishers' Council (EPC), the International Association of Scientific, Technical and Medical Publishers (STM), the European Bureau of Library, Information and Documentation Associations (EBLIDA), the Conference of European National Librarians (CENL), the Association of European Research Libraries (LIBER), European Visual Artists (EVA), the European Federation of Journalists (EFJ) and the International Federation of Reprographic Rights Organisations (IFRRO).

${ }^{15}$ It can be consulted on: http://ec.europa.eu/internal_market/copyright/docs/copyright-infso/20110920mou_en.pdf.

${ }^{16}$ Communication from the Commission to the European Parliament, the Council, the European Economic and Social Committee and the Committee of the Regions "Towards a modern, more European copyright framework", COM (2015) 626 final. 


\subsection{The French experience ${ }^{17}$}

The option of Article 7 of the Proposal for a Directive cannot be understood if the French legislation on out-of-commerce books and the CJEU's judgment Soulier and Doke on the case C-301/15 of November 16, 2016, are not taken into account.

In France, in February 2011, an agreement was concluded between the Ministry of Culture, the SNE (Syndicat national de l'édition), the National Library of France and the SGDL (Société des gens de lettres), in order to promote a system for making available discontinued books, and which led to a legislative reform that is discussed below.

Law 2012-287 and its regulatory development (Decree No. 2013-182 of February 27) design a system of contractual licenses for works out-of-commerce.

In short ${ }^{18}$, Law 2012-287 in its first chapter has introduced, through the introduction of a Chapter IV to Title III of Book One of the first part of the French Code of Intellectual Property (CPI) - Articles L 134-1 to L 134-9 -, a system for making available on the market works created during the twentieth century and "unavailable" - in its literal translation - to the public.

Likewise, its second Article creates an Article L 113-10, within the third Chapter of the same Title III of the first book CPI, to define orphan works, although without developing a specific regime for them. Finally, the third Article refers to a compromise agreement between the representative bodies of the authors, publishers, booksellers and printers to arrange the economic and legal issues related to the printing of books on demand.

It is not a general regulation of the phenomenon of out-of-commerce works, but a regulation applicable to the book sector and specialized magazines.

It understands by unavailable work, in terms of Article L 134-1 CPI, a book published in France before January 1,2001 and that is no longer the object of commercial diffusion by an editor and that, at present, neither is the subject of a printed or digital publication. Therefore, to be part of the digitization project promoted by the legislator, it must meet cumulatively with the three requirements: book published before January $2001^{19}$, which is not being marketed by the publisher and is not currently subject of a printed or digital publication. The out-of-commerce works do not lose this condition by being in the second-hand market.

Availability is referred, therefore, to commercial diffusion carried out by an editor, in paper or digital format.

The most critical point of the designed system consists of a mandatory opt-in in a database created for this purpose, accompanied by the possibility that from that inclusion in the database, the author and the publisher of an unavailable work can, within a period of six months, express their opposition by means of a notification, in writing, addressed to the responsible management entity. This opposition will be

\footnotetext{
${ }^{17}$ The French experience was the one that had the greatest impact on the proposal for a Directive, following the Soulier and Doke case, but it must be remembered that Germany also has a special rule for the issue of out-of-commerce works, introduced with regard to the transposition of Directive 2014/26/EU: para. 51, 52 of the Gesetz über die Wahrnehmung von Urheberrechten und verwandten Schutzrechten durch Verwertungsgesellschaften, applicable to works published before 1966.

${ }^{18}$ A summary in Jane C. Ginsburg, "Fair use for free, or permitted-but-paid?", Berkeley Technology Law Journal 29 (2014): 1425-1430.

${ }^{19}$ In its Explanatory Memorandum it is explained that in the election of the date from which books can be introduced in the system, the verification was taken into account that only after 2001 has the requirement of the editors been generalized that in The publishing contracts should include the assignment of the rights for making the works subject to the contract available online.
} 
annotated in the database (Article L 134-4, I CPI). Likewise, the publisher who has exercised his right of opposition assumes the obligation to carry out an effective exploitation of the work, in the two following years, since otherwise, the mention of opposition in the registry will be cancelled, and the work will return to the system. The proof of effective exploitation will correspond to the editor (Article L 134-4 II CPI).

Once a book has been registered and after six months, the management entity authorized for this purpose by the Ministry of Culture (the Sociéte de Perception et de Répartition des droits - SPRD), should send the editor of the work in printed format a proposal, in writing, for the exploitation of it (with an exclusivity of ten years, tacitly renewable), which will be rejected if the publisher does not notify his decision in writing, within a period of two months. From that moment, the SPRD may authorize the reproduction and making available in digital format of the work, through a system of paid, non-exclusive licenses, which will last for five years, renewable (Article L 134-3 I. CPI).

However, the passage of the period of six months indicated above does not mean that there is no longer the possibility of the author or editor recovering the exercise of the exploitation powers of the work. For the time being, after its expiration, the author of the unavailable book may object if he understands that the conditions of exploitation of their work are liable to damage their honour or reputation (Article L 134-4 CPI).

In that case, the rights of the publisher and the public interest in the availability of unavailable works give way to the author's moral right. It does not stop being, however, a restrictive system of exercise of rights, because unlike the unpublished right in which the moral right of the author is recognized to decide the fate of his/her work, whether it will be published or not and in what shape, once the work is disclosed, the possibilities of withdrawal are drastically reduced. At that point, once introduced into the system designed by French law, for the exercise of the right to object to the use of the work is made by the allegation and proof that such exploitation of the work is likely to injure their honour or reputation.

Soon the French editors and authors were very critical of this system, because they saw a clear violation of the publishing contracts in force, and the consecration of a kind of "public domain anticipated", with expropriation dyes, without offering them sufficient guarantees.

\subsection{Judgment of the CJEU, Third Chamber, on case C-301/15, Soulier and Doke, of 16 November 2016}

Against the background of the critical voices of the French publishing universe, the CJEU's judgment dealt with the adaptation to EU law of the French system on the availability of out-of-commerce works described above. The preliminary ruling question concerns the interpretation of Article 2(a) and 3(1) of Directive 2001/29/ EC of 22 May 2001 on the harmonization of certain aspects of copyright and related rights in the information society. ${ }^{20}$

\footnotetext{
${ }^{20}$ This petition has been submitted in the context of a dispute between Mr. Marc Soulier and Ms. Sara Doke, on the one hand, and the Premier Ministre (Prime Minister, France) and the Ministre de la Culture et de la Communication (Minister of Culture and Communication, France), on the other hand, in relation to the legality of the Décret No 2013-182, portant application of articles L. 1341 to L. 1349 du code de la propriété intellectuelle et relatif à l'exploitation numérique des livres unavailable du XX ${ }^{\text {ème }}$ siècle (Decree No 2013-182, of application of articles L. 1341 to L. 1349 of the Code of Intellectual Property and relating to the digital exploitation of books not available in the 20th century), of 27 February of 2013.
} 
The aforementioned precepts stipulate, respectively, that the Member States attribute authors the exclusive right to authorize or prohibit the direct or indirect reproduction of their works, by any means and in any form [Article 2(a)], as well as the exclusive right to authorize or prohibit the communication to the public of their works [Article 3(1)]. As a whole, they indicate that it must be considered that any use of a work by a third party without such prior consent violates the rights of the author of said work.

The final conclusion of the ruling is that the precepts analysed should be interpreted as meaning that they are opposed to a national regulation, such as the one at issue in the main proceedings, which attributes to a recognized copyright collection and distribution society the exercise of the right. to authorize the reproduction and communication to the public, in digital format, of "unavailable" books, that is to say, of books published in France before January 1, 2001 that are no longer the objects of commercialization or publication in printed format or digital, at the same time that allows the authors or the beneficiaries of such books to oppose or put an end to said exercise under the conditions established by the regulations themselves.

In its judgment of June 7, 2017, the French Council of State endorsed the decision of the Court of Justice of the European Union of November 16, 2016, which ruled that, on the one hand, the lack of effective and individualized prior information of the authors that the works are digitized and, on the other hand, the obligation imposed on authors wishing to exercise their right of withdrawal to demonstrate that they are the sole owners of reproduction rights was contrary to the requirements of European Union law. In this way, it annuls Article 1 of the decree of February 27, 2013 (and therefore Articles R134-5 to R 134-10 of the CPI), contrary to the European Directive of 2001 in relation to copyright, but it clarifies that the decision does not have retroactive effects, and consequently, the contracts celebrated under its validity maintain their effects.

\section{Critical analysis of the regime of out-of-commerce works in the Proposal for a Directive}

With the background described, the Proposal for a Directive did not abandon the contractual path for everything related to out-of-commerce works, but decided to create a tool restricted to cultural heritage institutions, in a clear connection with the system implemented by the Directive of orphan works that creates an unpaid limit in favour.

As can be deduced from the results of the expost evaluations, from the consultations with the interested parties and from the impact evaluations, on the subject of off-line commercial works, two options were proposed. On the one hand, Option 1 was to require Member States to apply legal mechanisms, with cross-border effect, to facilitate licensing agreements on books and specialized journals out-of-commerce and to organize a dialogue between interested parties at national level with a view to facilitating the application of that mechanism. On the other hand, option 2 went further, since it applied to all types of works outside the commercial circuit, since the extension was considered necessary to address the licensing of works that are outside the commercial circuit in all sectors. Therefore, the Proposal promotes this second option.

In summary, in Title III of the Proposal for a Directive, Article 7 requires Member States to establish a legal mechanism that facilitates work license agreements and other benefits outside the commercial circuit. Article 8 guarantees the cross-border effect 
of these license agreements. Article 9 requires Member States to maintain a dialogue between interested parties on issues relating to Articles 7 and 8. Article 10 requires Member States to establish a negotiating mechanism to facilitate agreements on the online exploitation of audio-visual works.

For the purposes of the Proposal, a work or other benefit will be considered outof-commerce when the entire work or other benefit, in all its translations, versions and manifestations, is not available to the public through usual commercial channels and it cannot reasonably be expected to be. It is not established, as in the French case (works published before 2001) or German (works published before 1966), a specific period of time.

The beneficiaries of the license will be cultural heritage institutions. In the articles of the Proposal, there is no definition of them, but in its Explanatory Memorandum, reference is made to libraries or museums accessible to the public, archives or organisms for the conservation of cinematographic or sound heritage.

To determine the objective element of the lack of public availability in commercial channels - unlike the process of determining the orphan works of Directive 2012 a process of thorough search prior to the introduction of the work in a common database is not imposed.

In any case, it must be presumed that the subjects involved act on the parameters of good faith and the innocuous use of their rights to qualify a work out-of-commerce even because the right holders are called to participate in said process.

In this sense, the concern is rather directed towards the obstacles that can be placed on cataloguing as a work outside the commercial circuit. Therefore, the second paragraph of Article 7 of the Proposal for a Directive states that Member States, in consultation with right holders, collective management entities and cultural heritage institutions, will ensure that the requirements that are applied to determine whether works and other benefits may be subject to licensing in accordance with paragraph 1 , are not stricter than is necessary and reasonable and do not exclude the possibility of determining that a collection is out-of-commerce as a whole, when it is reasonable to assume that all works or other features of the collection are.

At the heart of the system, therefore, are the collective entities for the management of copyright, the object of an important crisis of legitimacy in recent years. ${ }^{21}$

In effect, the licensing mechanism described in Article 7(1) is based on the premise that Member States will ensure that, when a collective management entity agrees on behalf of its members a non-exclusive license for non-commercial purposes ${ }^{22}$ with a

\footnotetext{
${ }^{21}$ Significant the Amendment presented in the European Parliament: "In the event that there is no collective management entity or that a collective management entity does not adequately represent rights holders rights, Member States should provide for exceptions for the institutions of cultural heritage, research organizations and educational centers, both formal and non-formal, distribute, communicate to the public or make available works that are outside the commercial circuit for non-commercial purposes. Member States shall ensure that any unreasonable damage to the legitimate interests of right holders is adequately remunerated and that all right holders can object at any time to the use of their works".

${ }^{22}$ Principle number 1(3) of the MoU does not exempt the commercial use of the works: "Without prejudice to existing exceptions and limitations in the copyright legislations of the Member State in which the publicly accessible cultural institutions are located, each Agreement shall define commercial or non-commercial uses and shall specify which uses are authorised'. This point was valued positively with the Economic and Social Committee, according to which :"2.7.2: Finally, the proposal for a directive also introduces ways of making it easier for cultural heritage institutions to license rights, as required for the digitisation and dissemination of works that are out-of-commerce but hold great cultural value. Access to works in non-commercial settings, such as educational organisations, public libraries or non-theatrical venues, is also very important for nurturing cultural diversity, for educational purposes and to encourage
} 
cultural heritage institution for digitisation, distribution, communication to the public or making available to works or other benefits that are out-of-commerce and are permanently in the collection of the institution, this non-exclusive license may be extended or may be assumed applicable to the holders of rights in the same category as those covered by the license that are not represented by the collective management entity, provided that:

a) the collective management organisation is, based on mandates from right holders, broadly representative of right holders in the category of works or other subject-matter and of the rights which are the subject of the licence;

b) equal treatment is guaranteed to all rightholders in relation to the terms of the licence;

c) all rightholders may at any time object to their works or other subject-matter being deemed to be out of commerce and exclude the application of the licence to their works or other subject-matter.

The uses allowed by the license are non-commercial, but this does not prevent revenue from being generated to cover the costs of the license. This is expressed in Recital 27 of the Proposal for a Directive according to which "as mass digitisation projects can entail significant investments by cultural heritage institutions, any licences granted under the mechanisms provided for in this Directive should not prevent them from generating reasonable revenues in order to cover the costs of the licence and the costs of digitising and disseminating the works and other subject-matter covered by the licence".

The possibility of managing licenses of holders partners or not, of the entity, requires a transparent representative model that ensures a balanced management of interests ${ }^{23}$, because otherwise the criteria set by the Soulier and Doke case would be breached. Therefore, in the EU context, the collective management entity competent to manage the license will be determined according to the following premises:

"Article 7(4): MemberStates shall ensure that the licences referred to in paragraph 1 are sought from a collective management organisation that is representative for the Member State where: (a) the works or phonograms were first published or, in the absence of publication, where they were first broadcast, except for cinematographic and audiovisual works; (b) the producers of the works have their headquarters or habitual residence, for cinematographic and audiovisual works; or (c) the cultural heritage institution is established, when a Member State or a third country could not be determined, after reasonable efforts, according to points (a) and (b)".

However, in the path marked by the CJEU's ruling of November 16, 2016, the licensing system must be based on a clear opposition system that allows rights holders to access and request the exclusion of the out-of-commerce work. For this reason, the opt-out is a hinge that ensures the operation of the gear, because the Directive imposes the design of an advertising of the contents and how to access them and exercise the right of opposition.

participation in society. Furthermore, the Commission is, together with European Film Agency Directors (EFADs) and the audio-visual industry, exploring the possibility of creating and funding a catalogue of European films for educational purposes in 2017'. Opinion of the European Economic and Social Committee on the 'Proposal for a Directive of the European Parliament and of the Council on copyright in the Digital Single Market', of 25 January 2017.

${ }^{23}$ See recital 24 of the Proposal for a Directive. 
In this line, advertising is directed, in accordance with Article 7(3) of the Proposal for a Directive, first, to the consideration of the works or other services as out-of-commerce, as well as to the license, in particular, its application to holders of rights not represented. Thus, knowing the assignment of the work to the category of outside trade and possible licenses, secondly, there is an inescapable obligation to publicize the possibility that the owners of the rights express their opposition, even during a period of reasonable time before the works or other benefits are digitised, distributed, communicated to the public or made available.

For it to be effective, as with the database of orphan works, it will be up to $\mathrm{EUIPO}^{24}$ to make that information available to citizens in a single public access portal, for a sufficient period of time before that cross-border use takes place. ${ }^{25}$

Finally, it should be noted that the Proposal for a Directive does not establish anything regarding compensation. The fact that the uses are not commercial does not necessarily imply that the licenses are free, since, in addition to the administration costs, a variation in their costs is common in the scope of the exploitation license for works, depending on the scope of the granted uses.

By way of conclusion, it is mandatory to investigate the reason for opting for a legislative solution.

The publication of the MoU in 2011 already raised the question as to why an $\mathrm{MoU}$ is needed. Why is the Commission not proposing a legislative initiative? The same Commission then offered the answer:

"copyright holders, whether authors or publishers, are the ones who can decide whether or not to permit libraries or other cultural institutions to digitise out-of-commerce works contained in their collections and put them online as part of a digital library project. Through voluntary agreements interested parties can negotiate mutually acceptable terms and conditions for the online exploitation of out-of-commerce works. This is preferable to legislation that could be too prescriptive and lack the flexibility to provide solutions adapted to the needs of particular users and the specificities of particular sectors while fully respecting copyright. The Key Principles contained in the MoU signed today contain the necessary elements to ensure sufficient flexibility enabling authors and publishers to mandate collective management organisations to grant national and multi-territorial licences to those libraries and other publicly accessible cultural institutions wanting to digitise and make available out-of-commerce books and learned journals in their collections. In turn, the MoU recognises that legislative backing for these licensing solutions voluntarily developed by stakeholders may be needed in some Member States in order to cover situations where licences include right holders that are not members of a collective management organization". ${ }^{26}$

For this reason, the question about the reasons that now justify this initiative in the framework of the Proposal for a Directive is pertinent. Basically, the content of Title II of said Proposal faithfully reflects the principles described in the MoU, but we can frame it in a double sense. On the one hand, it reinforces the criterion of

\footnotetext{
${ }^{24}$ Regulation (EU) 386/2012 of the European Parliament and of the Council attributes to the Intellectual Property Office of the European Union certain tasks and activities, financed with its own budgetary resources, which are intended to facilitate and support the activities of national authorities, the private sector and the Union institutions in the fight against the infringement of intellectual property rights, including their prevention. It is therefore appropriate to entrust the Office with the establishment and management of the European portal that provides this information.

${ }^{25}$ See recital 28 of the Proposal for a Directive.

${ }^{26} \mathrm{http}: /$ / europa.eu/rapid/press-release_MEMO-11-619_en.htm?locale=en.
} 
the Soulier and Doke case, insofar as it requires a negotiated and transparent system of access and opposition. On the other hand, it evidences to a large extent the difficulties (economic and legal) that many of these institutions they have found before the system of unpaid limit for the use of orphan works. ${ }^{27}$ Regarding this last aspect, the licensing system is less complex than diligent search processes, a factor to be taken into account in the planning of the processes of massive digitization of the funds of cultural institutions dedicated to the preservation of cultural heritage.

\footnotetext{
${ }^{27}$ Without going deeply into the matter, it is enough to consult the EUIPO orphan works data base to verify that the system has not met the expectations of the impact of Directive 2012. Registration is very limited and comes, for the most part, from of countries that already had legislation on orphan works, before the transposition by the Member States of the aforementioned Directive.
} 